\title{
Variation in the Thyrotropic Activity of Human Chorionic Gonadotropin in Chinese Hamster Ovary Cells Arises from Differential Expression of the Human Thyrotropin Receptor and Microheterogeneity of the Hormone*
}

\author{
R. HOERMANN, S. POERTL, I. LISS, S. M. AMIR, AND K. MANN \\ Division of Endocrinology, Department of Medicine, University of Essen, D-45122 Essen; and Medical \\ Department II, Klinikum Grosshadern, University of Munich (S.P., I.L.), D-81377 Munich, Germany; \\ and the Division of Research Grants, National Institutes of Health (S.M.A.), \\ Bethesda, Maryland 20892
}

\begin{abstract}
The role of hCG as a stimulator of the human thyroid has been a subject of controversy, because discrepant results have been obtained in different in vitro assays. In an attempt to explain the variation observed in the thyroid response to hCG, we investigated the ability of hCG and that of its isoforms and glycosylation variants to inhibit $\left[{ }^{125} \mathrm{I}\right]$ bovine $(\mathrm{b})$ TSH binding and stimulate adenylate cyclase in two clones, JP09 and JP26, of Chinese hamster ovary cells stably transfected with the human TSH receptor (hTSHr). The two clones differed with respect to the number of hTSHr expressed per cell (34,000 in JP09 and 2,000 in JP26 cells). Both responded extremely well to bTSH; the cAMP response to 0.001 IU/L bTSH was distinguishable from basal values. Interestingly, JP09 cells were readily stimulated by hCG $\left(20-100 \mathrm{mg} / \mathrm{L} ; 0.52-2.6 \times 10^{-6}\right.$ $\mathrm{mol} / \mathrm{L}$ ) to release cAMP, whereas JP26 cells showed little if any response. Also, cAMP stimulation produced by asialo-hCG was 12-fold in JP09 cells and only 4-fold in JP26 cells compared to 45- and 67-fold stimulations by bTSH, respectively. Stimulation by asialo-hCG was approxi-
\end{abstract}

mately $30 \%$ that of bTSH in JP09 cells, but less than $6 \%$ in JP26 cells. When assessing the thyrotropic activity of the microheterogeneous isoforms of hCG, more alkaline $\mathrm{pI}$ forms were found to be more active than those of a more acidic $\mathrm{pI}$ regardless of whether they were derived from normal or molar pregnancy urine. Further studies with hCG, asialohCG, asialoagalacto-hCG, and deglycosylated hCG revealed that removal of sialic acid caused a marked increase in both its affinity for hTSHr and its cAMP-releasing potency, whereas removal of further carbohydrate, although it slightly enhanced receptor binding, was detrimental to adenylate cyclase activation.

In conclusion, differences in hTSHr expression may cause a variation in the cAMP response to hCG or its glycosylation variants, as does the microheterogeneity of the hormone itself. These mechanisms may be responsible at least in part for the divergent responses of different cell types to hCG and render interpretation of the physiological meaning of the data obtained in recombinant receptor systems difficult. (J Clin Endocrinol Metab 80: 1605-1610, 1995) $\mathrm{h}$ CG exhibits considerable homology in its structure with human TSH (hTSH) as does CG/LH receptor with TSH receptor (TSHr) (1-3). As a result, this hormone has been reported to possess significant thyrotropic activity, which may be clinically relevant in hyperthyroidism of pregnant women and patients with trophoblastic tumors (4). However, its role as a thyroid stimulator has been a subject of controversy, because in vitro studies have shown a wide variation in the thyroid response to hCG (5-12).

Therefore, to elucidate possible factors that may account for the variation observed in the in vitro thyroid response to $\mathrm{hCG}$, we investigated the interaction of hCG with recombinant human TSHr (hTSHr) expressed in Chinese hamster ovary (CHO)

Received August 30, 1994. Revision received December 30, 1994. Accepted January 6, 1995.

Address all correspondence and requests for reprints to: Dr. Rudolf Hoermann, M.D., Division of Endocrinology, Department of Medicine, University of Essen, Hufelandstrasse. 55, D-45122 Essen, Germany.

* Portions of these findings have been presented in abstract form at the 76th Annual Meeting of The Endocrine Society, Anaheim, CA, 1994 (Abstract 109), and the 68th Annual Meeting of the American Thyroid Association, Chicago, IL, 1994 (Abstract 150). This work was supported in part by a grant from the Deutsche Forschungsgemeinschaft, Bonn, Germany (to R.H.) cells. To study the variability related to hTSHr expression, we assessed [ $\left.{ }^{125} \mathrm{I}\right] \mathrm{bTSH}$ binding inhibition and CAMP stimulation induced by bTSH and hCG in two different clones of CHOTSHr cells stably transfected with the hTSHr. Further, to evaluate the variability related to the microheterogeneity of the hormone itself, we assessed the thyrotropic activities of naturally occurring isoforms of hCG derived from either normal or molar pregnancy urine. To more precisely define the role of carbohydrate in this respect, the glycosylation variants, asialo$\mathrm{hCG}$, asialoagalacto-hCG, and deglycosylated hCG, were also tested for their bTSH binding-inhibiting and CAMP-stimulating activities in CHO-TSHr cells.

\section{Materials and Methods}

\section{Materials}

Labeled bTSH was purchased from Henning (Berlin, Germany), and the unlabeled hormone $(\sim 30 \mathrm{IU} / \mathrm{mg})$ was obtained from Armour Co. (North Chicago, IL). Crude urinary pregnancy hCG ( $\sim 2500 \mathrm{IU} / \mathrm{mg}$ ) was obtained from Ayerst (Rouses Point, NY). Highly purified hCG (CR123), used for standardization, was supplied by the Hormone Distribution Program of the NIDDK (Bethesda, MD). Immobilized neuraminidase from Clostridium perfringens (type VI-A) and $\beta$-galactosidase were purchased from Sigma Chemical Co. (Deisenhofen, Germany); cell culture 
reagents were obtained from Gibco-BRL (Eggenstein, Germany) and Seromed (Berlin, Germany); and cAMP RIA kits were purchased from Amersham (Braunschweig, Germany).

Two clones, JP09 and JP26, of CHO cells stably transfected with complementary DNA for the hTSHr were kindly provided by Drs. Maenhaut and Vassart, University of Brussels (Brussels, Belgium) $(13,14)$.

\section{Preparation of $h C G, h C G$ isoforms, and carbohydrate- modified variants of $h C G$}

Highly purified hCG $(\sim 12,000 \mathrm{IU} / \mathrm{mg})$ was isolated from crude pregnancy hCG by sequential chromatography on columns of DEAE-52 and Sephadex G-100 (Pharmacia, Freiburg, Germany), as described previously (15). Crude molar hCG extracted from the urine of eight euthyroid patients with hydatidiform moles was pooled and purified using the procedure employed for purification of hCG.

The isoforms of hCG were prepared by chromatography of purified pregnancy (hCGp) or molar hCG (hCGm) on a column of Mono S 5/5 (Pharmacia, Freiburg, Germany), combining the fractions eluted into three pools (pools I-III). The pools were shown by isoelectric focusing to comprise pI forms of hCG ranging from 3.9-4.1 (pool l), 4.1-5 (pool II), and greater than 5 (pool III).

To obtain asialo-hCG, purified hCG was desialylated by digestion with neuraminidase, following the protocol of van Hall et al. (16), which had been previously employed in our laboratory $(11,15,17)$. Asialoagalacto-hCG was obtained by further enzymatic digestion of asialo-hCG with $\beta$-galactosidase (17). hCG lacking almost all of its carbohydrate moiety (deglycosylated hCG) was prepared by treating hCG with anhydrous hydrogen fluoride, as described in detail previously (18).

To define their purity and other properties, the hCC preparations were subjected to sodium dodecyl sulfate-polyacrylamide gel electrophoresis (under reducing and nonreducing conditions) and analyses of their amino acid composition and contents of sialic acid, galactose, and other carbohydrates before and after treatment with the various enzymes and chemicals. We also determined their immunological activities by various immunometric assays specific for holo-hCG, free $h C G \beta$, hCG $\beta$ core fragment, or hCG $\alpha$ and their abilities to inhibit $\left[{ }^{125} I\right] h C G$ binding to rat testicular membranes. The main results of these studies have been reported previously $(15,17,18)$. The purity, immunological activity, and hCG receptor binding potency of the substances used in the present studies were comparable to those of the standard preparation of hCG (CR123). Removal of sialic acid and galactose residues was more than $80 \%$ complete, as measured by the colorimetric method of Warren (19) and the copper reduction method of Somogyi and Nelson (20), respectively. Deglycosylation removed $60-80 \%$ of the total carbohydrate, with substantial amounts of $\mathrm{N}$-acetylglucosamine and $\mathrm{N}$-acetylgalactosamine still remaining attached $(18,21)$.

The mol wt of the hormone preparations used were estimated to be: bTSH, 28,000; purified hCG, 38,000; asialo-hCG, 34,500; asialoagalactohCG, 33,000; and deglycosylated hCG, 30,000.

\section{Cell culture}

Two clones of CHO cells stably transfected with the hTSHr (CHOTSHr cells JP09 and JP26) and the CIIO wild-type cells (CHO cells), which served as controls, were grown in $75-\mathrm{cm}^{2}$ culture flasks in Ham's F-12 Medium containing $1 \mathrm{mmol} / \mathrm{L}$ sodium pyruvate, $100,000 \mathrm{IU} / \mathrm{L}$ penicillin, $100 \mathrm{mg} / \mathrm{L}$ streptomycin, $2.5 \mathrm{~g} / \mathrm{L}$ amphotericin- $\mathrm{B}$, and $5 \%$ fetal calf serum. The cells were cultured under an atmosphere of $5 \% \mathrm{CO}_{2}$ and passaged every $3-4$ days.

\section{Studies of binding to CHO-TSHr cells}

To study the binding of ${ }^{125} \mathrm{I}$-labeled bTSH, cells were transferred to 24-well plates $\left(\sim 7 \times 10^{5}\right.$ cells/well) and incubated together with the tracer $(\sim 6,000 \mathrm{cpm} ; \mathrm{SA}, 40,000-60,000 \mathrm{Ci} / \mathrm{kg})$ and the respective cold ligands at $4 \mathrm{C}$ for $24 \mathrm{~h}$ in modified sodium-free Hanks' buffer supplemented with $278 \mathrm{mmol} / \mathrm{L}$ sucrose and $0.1 \%$ BSA $(11,18)$. At the end of the incubation period, the supernatant was removed, the cells were washed and solubilized with $0.5 \mathrm{~mL} 1 \mathrm{~N} \mathrm{NaOH}$, and their ${ }^{125} \mathrm{I}$ content was measured in a $\gamma$-counter. Nonspecific binding was determined by the addition of an excess of unlabeled bTSH (500 IU/L) and subtracted from total binding to yield specific binding values, which are shown in the figures.

\section{cAMP measurement in CHO-TSHr cells}

Cells transferred to 96 -well plates $\left(\sim 10^{5}\right.$ cells $/$ well $)$ and maintained in culture medium for 3 days were incubated, in the presence of 1 mmol/L 1-methyl-3-isobutylxanthine, with various concentrations of bTSH or the various hCG forms for $2 \mathrm{~h}$ at $37 \mathrm{C}$ in Krebs-Ringer bicarbonate buffer. The cAMP concentration was measured in an aliquot of the supernatant by a commercially available KIA $(11,18,22)$.

\section{Isoelectric focusing}

Isoelectric focusing of hCG was carried out on a $7 \%$ acrylamide gel (150 × $60 \times 0.48 \mathrm{~mm}$; Pharmacia) containing 3\% Servalyt 3-6 (Serva, Heidelberg, Germany) under the following conditions: $2000 \mathrm{~V}, 200$ mamp, maximum 15 watts, $10 \mathrm{C}, 1 \mathrm{~h}$. The bands were specifically stained with a monoclonal holo-hCG antibody, as described previously (23-25).

\section{Statistical methods}

For statistical comparison of data, Wilcoxon's test for unpaired observations was used.

\section{Results}

\section{Characterization of the CHO-TSHr cell clones JPO9 and JP26}

We compared bTSH binding and cAMP production in the CHO wild-type cells and the CHO-TSHr cell clones, JP26 and JP09. Specific [ $\left.{ }^{125} \mathrm{I}\right] \mathrm{bTSH}$ binding was less than $1 \%$ to $\mathrm{CHO}$ cells, 5-7\% to JP26 cells, and 26-30\% to JP09 cells. Displacement by increasing concentrations of unlabeled bTSH and Scatchard analysis of the data revealed that JP09 cells had a much higher bTSH-binding capacity than JP26 cells (Fig. 1a). The difference in the binding capacity of the clones was apparently related to the number of hTSHr expressed per cell, which was estimated to be 34,000 in JP09 and 2,000 in JP26 cells (Fig. 1a). Basal cAMP activity and bTSH-stimulated cAMP production were higher in JP09 cells than in JP26 cells. The ratio of maximum bTSH stimulation to basal activity, however, was lower in JP09 than in JP26 cells ( $\sim 45$ vs. 67; Fig. 1 b). The wild-type cells, as expected, were unresponsive to bTSH stimulation (data not shown).

\section{Responses of the CHO-TSHr cell clones JP09 and JP26 to $h C G$ and asialo- $h C G$}

We assessed the inhibition of $\left[{ }^{125} \mathrm{I}\right] \mathrm{bTSH}$ binding to $\mathrm{CHO}$ TSHr JP09 and JP26 cells by hCG and asialo-hCG. Although hCG itself displayed little binding-inhibiting activity in either cell clone, asialo-hCG was much more potent in this respect; its $\mathrm{ID}_{50}$ was $20 \mathrm{mg} / \mathrm{L}\left(5.8 \times 10^{-7} \mathrm{~mol} / \mathrm{L}\right)$ in JP09 cells and $7 \mathrm{mg} / \mathrm{L}\left(2.0 \times 10^{-7} \mathrm{~mol} / \mathrm{L}\right)$ in JP26 cells (Fig. 2a). With respect to cAMP activation, a significant $(P<0.01$, combined data from three closely concurring experiments with triplicate determinations), although not very impressive, cAMP increase over basal values in response to hCG stimulation was observed in JP09 cells, whereas little if any stimulation was seen in JP26 cells (Fig. 2b). The difference in the response of the two clones was more pronounced when cells were stimulated with asialo-hCG (Fig. 2b). Asialo-hCG stimulated 

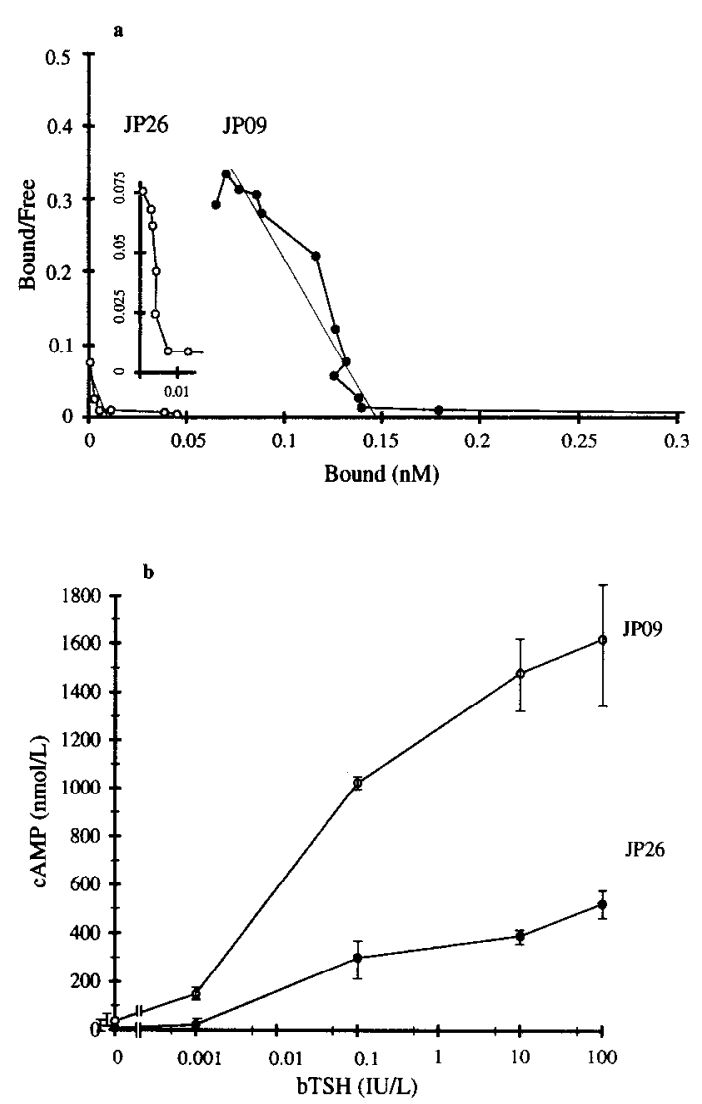

FIG. 1. bTSH binding (a; Scatchard plots) and cAMP stimulation by bTSH (b) in two different clones, JP09 and JP26, of CHO cells expressing hTSHr. JP09 cells displayed a markedly higher binding capacity than JP26 cells. Because cell number, DNA content, amount of protein, and affinity for hTSHr were comparable in these experiments, the difference in binding capacity was attributable to the number of hTSHr expressed per cell. This was estimated to be 34,000 in JP09 and 2,000 in JP26 cells. The inset shows the plot for JP26 cells with an expanded scale. Consistent with their increased receptor number, cAMP production was higher in JP09 cells. The ratio of basal to bTSH-stimulated values, however, was higher in JP26 cells. The values shown represent the means of closely concurring duplicate determinations for specific $\left[{ }^{125} \mathrm{I}\right] \mathrm{bTSH}$ binding and the mean $\pm \mathrm{SD}$ (n $=3$ ) for cAMP determinations. The marked differences between the two cell clones shown here have been a constant finding in three separate experiments.

JP09 cells up to 12-fold and JP26 cells 4-fold over basal values. For comparison, maximum bTSH stimulation in the same experiment was 45-fold in JP09 cells and 67-fold in JP26 cells. Maximum stimulation by asialo-hCG amounted to $30 \%$ of that induced by bTSH in the same experiment in JP09 cells, but was less than $6 \%$ of the bTSH values in JP26 cells.

\section{Thyrotropic activity of hCG isoforms in CHO-TSHr cells}

Next, the in vitro thyrotropic potencies of hCG isoforms derived from pregnancy and molar hCG were assessed in CHO-TSHr JP09 cells. Pool II (pI 4.1-5) and pool III (pI >5) derived from hCGp were more active than pool I (pI 3.9-4.1) of hCGp in terms of the ability to both inhibit $\left[{ }^{125} \mathrm{I}\right] \mathrm{bTSH}$ binding and stimulate cAMP production (Fig. 3). Similarly, in the pools obtained from hCGm, a more alkaline pI was associated with increased thyrotropic activity (Fig. 3). When comparing hCGp and hCGm, on the other hand, the presence
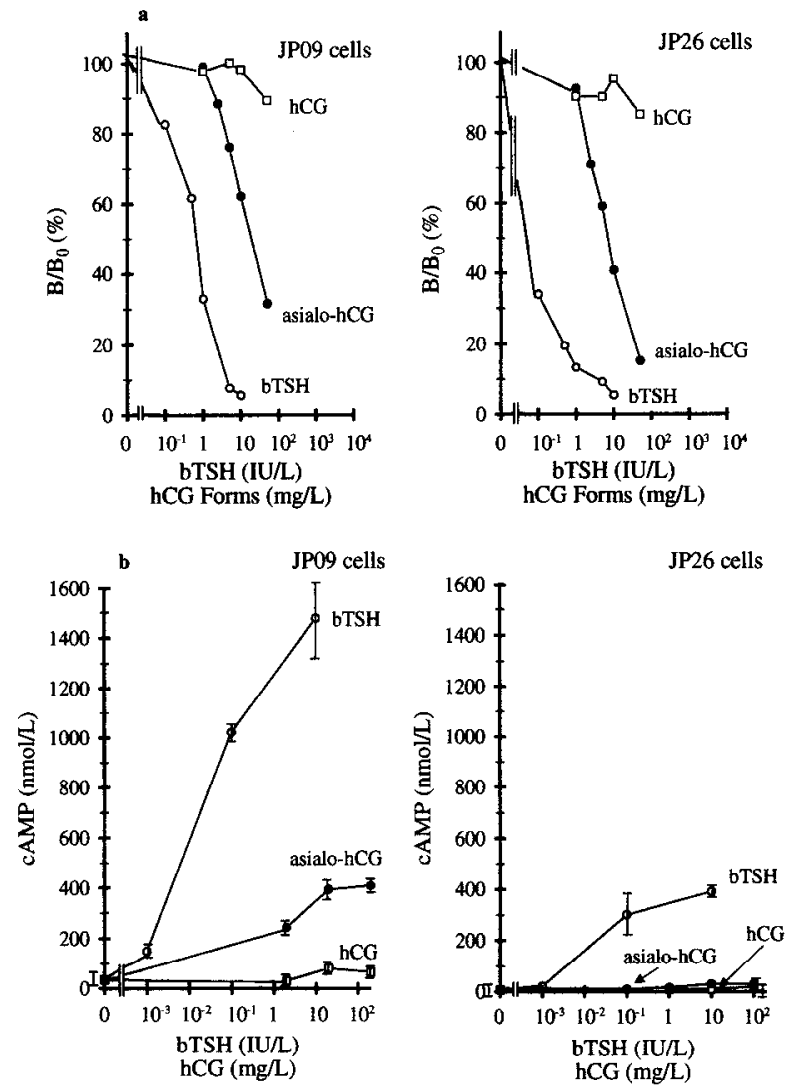

FiG. 2. Inhibition of $\left.{ }^{[25} \mathrm{I}\right] \mathrm{bTSH}$ binding (a) and stimulation of cAMP activity (b) in JP09 and JP26 cells by hCG and asialo-hCG. hCG shows a weak activity to inhibit $\left[{ }^{125} \mathrm{I}\right] \mathrm{bTSH}$ binding to both cells, and asialohCG is much more active in this respect. With respect to cAMP activation, JP09 cells were more responsive to stimulation by hCG or asialo-hCG than JP26 cells. Maximum stimulation by asialo-hCG amounted to $30 \%$ of that induced by bTSH in JP09 cells and to only $6 \%$ in JP26 cells. For hCG, a similar estimate could be obtained only in JP09 cells, because no appreciable hCG stimulation was observed in JP26 cells. The cAMP released by hCG was approximately $5 \%$ the amount of cAMP released by bTSH in JP09 cells. The values shown represent the means of closely concurring duplicates for specific binding data and the mean $\pm \mathrm{SD}(\mathrm{n}=3)$ for cAMP determinations. The data shown in this figure were confirmed in two other experiments.

of alkaline isoforms was about the same in the two preparations (Fig. 3, inset), and the cAMP-stimulating activity in CHO-TSHr cells was also similar (data not shown). The corresponding pools derived from hCGp or hCGm also did not differ in potency to bind to and stimulate cAMP release from CHO-TSHr cells (Fig. 3 ).

\section{Role of carbohydrate in $h C G$ for hTSHr binding and cAMP stimulation in CHO-TSHr cells}

The immunological activities of hCG, asialo-hCG, asialoagalacto-hCG, and deglycosylated hCG preparations employed in these studies were assessed by a specific holo-hCG assay and found to be comparable (data not shown).

As shown earlier, hCG itself showed little ability to inhibit $\left[{ }^{125} \mathrm{I}\right] \mathrm{bTSH}$ binding to CHO-TSHr cells (JP09), and desialylation of hCG resulted in a marked enhancement of its activity. Removal of additional galactose residues, on the other hand, caused only a minor increase in the affinity of hTSHr 

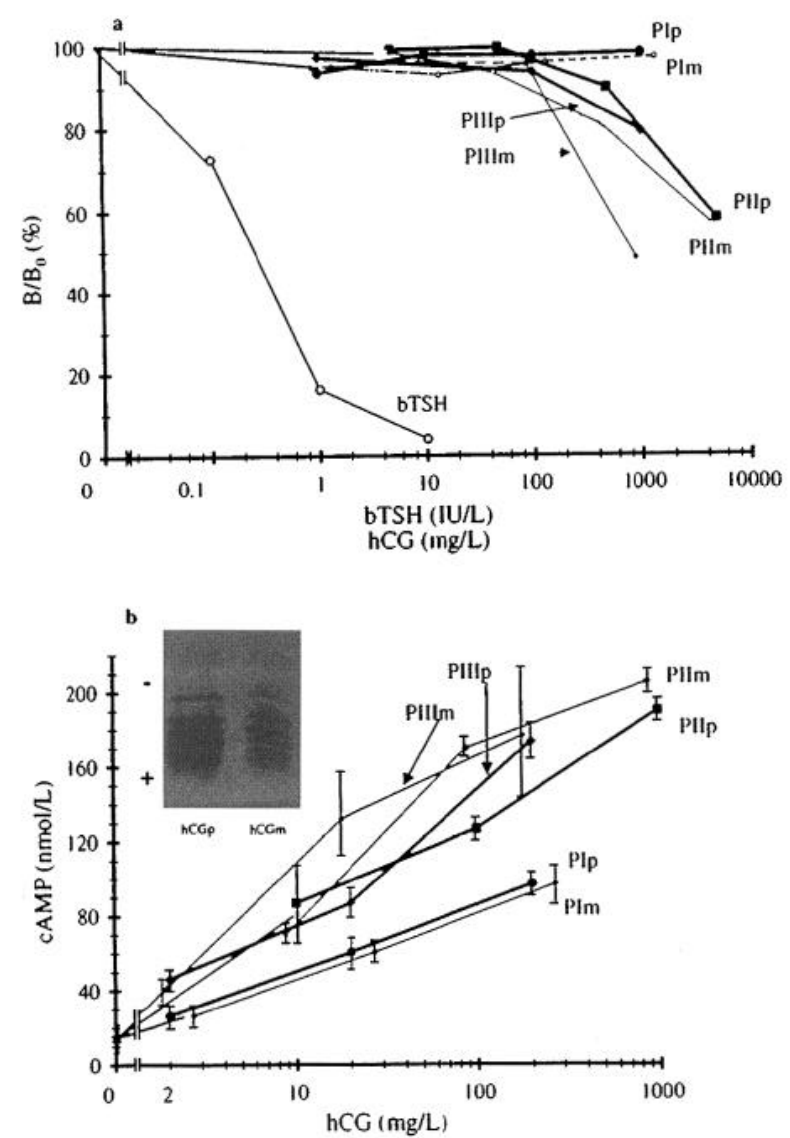

FIG. 3. Inhibition of $\left[{ }^{125} \mathrm{I}\right] \mathrm{bTSH}$ binding (a) and stimulation of cAMP activity (b) in CHO-TSHr JP09 cells by hCG isoforms derived from pregnancy (hCGp) or molar hCG (hCGm). The isoforms contained in hCGp and hCGm were visualized by isoelectric focusing (see inset) and fractionated into three pools by cathion exchange chromatography: pool I comprising the pI forms from $\mathrm{pI} 3.9-4.1$, pool II from $\mathrm{pI}$ 4.1-5.0, and pool III with $\mathrm{pI}$ above 5.0. The indices $\mathrm{p}$ and $\mathrm{m}$ indicate the origin of the pool from either hCGp or hCGm. The thyrotropic activities of the pools appear to be related to their pI values, but unrelated to their origin from hCGp or hCGm. The values shown represent the means of closely concurring duplicates for specific binding data and the mean $\pm \mathrm{SD}(\mathrm{n}=3)$ for cAMP determinations. The differences in $\left[{ }^{125} \mathrm{I}\right] \mathrm{bTSH}$ binding inhibition and cAMP stimulatory activity between the pools shown were the same as those observed in two other experiments.

for the modified hormone, as judged from its ability to inhibit $\left[{ }^{125} \mathrm{I}\right] \mathrm{bTSH}$ binding. Nearly totally deglycosylated hCG was intermediate to asialoagalacto-hCG and asialo-hCG in this respect (Fig. 4a). With respect to the functional activation of hTSHr by these ligands, asialo-hCG was clearly the most potent form of hCG, although its potency, when tested in the same experiment, approached only approximately $30 \%$ the activity of bTSH $(100 \mathrm{IU} / \mathrm{L})$. Asialoagalacto-hCG and deglycosylated hCG, on the other hand, were considerably less active as stimulators of cAMP release in $\mathrm{CHO}-\mathrm{TSHr}$ cells than asialo-hCG, but still more active than hCG itself, which was the least effective agent (Fig. 4b).

\section{Discussion}

The occurrence of hyperthyroidism in patients with trophoblastic tumors and some cases of normal pregnancy may
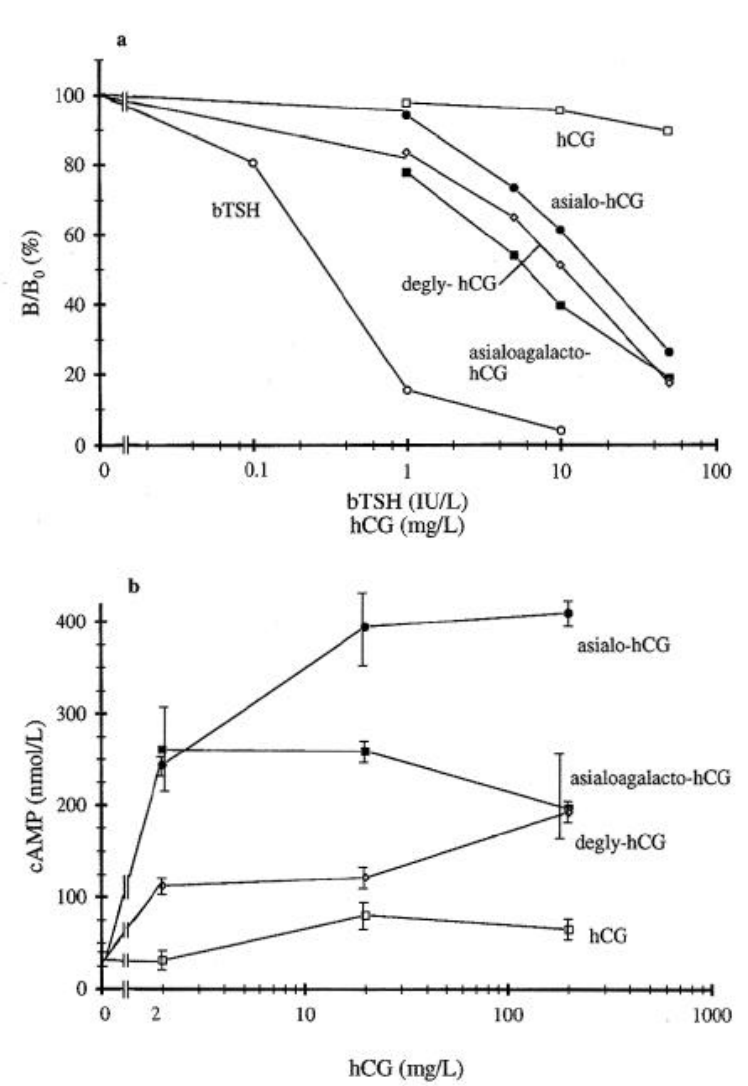

FIG. 4. Inhibition of $\left[{ }^{125} \mathrm{I}\right] \mathrm{bTSH}$ binding (a) and stimulation of cAMP activity (b) in CHO-TSHr JP09 cells by the hCG variants asialo-hCG, asialoagalacto-hCG, and deglycosylated hCG. Removal of sialic acid from hCG markedly enhances both the affinity to hTSHr and the intrinsic activity of the hormone, whereas removal of further carbohydrates, although slightly favoring receptor binding, impairs receptor activation. At the maximum concentration tested $(100 \mathrm{IU} / \mathrm{L})$, bTSH released $1600 \mathrm{nmol} / \mathrm{L}$ cAMP (not shown). Each point represents the mean of closely concurring duplicates for specific binding data and the mean $\pm \mathrm{SD}(\mathrm{n}=3)$ for cAMP determinations in a single experiment, and the results concur closely with those obtained in two other experiments.

be explained by stimulation of the thyroid gland by hCG, which is present in exceedingly high concentrations in the circulation of these patients; a distinct molecular variant form of hCG with increased thyrotropic activity produced by the trophoblastic tumor or during pregnancy; or a combination of the two factors (7). With respect to the in vitro thyrotropic activity of hCG, most investigators were unable to demonstrate significant stimulation of the cAMP response in human thyroid membranes $(8-10,15)$. The same failure to stimulate cAMP activity in vitro has been observed in a human thyroid carcinoma cell line (HTC) expressing the recombinant hTSHr, but lacking endogenous hTSHr (11). In thyroid cells of rodent origin, on the other hand, including FRTL- 5 cells and CHO cells transfected with the hTSHr, hCG has been shown to readily evoke significant cAMP responses $(10,18,26-30)$. Clearly, the discrepancies seemed too pronounced to be explained by the use of different assay conditions.

To seek possible explanations for the variation observed in the thyroid response to hCG, we studied two clones of $\mathrm{CHO}$ cells that had been stably transfected with hTSHr. Remark- 
ably, the cAMP responses to $\mathrm{hCG}$ and its variant form asialohCG differed widely between the two clones. Although clone JP26 showed little, if any, response, clone JP09 was readily stimulated by hCG to release cAMP, with 1 IU of the hormone displaying a potency equivalent to $5 \times 10^{-6} \mathrm{IU} \mathrm{bTSH}$. A similar thyrotropic activity of hCG has recently been reported by Yoshimura et al. (30), who used the same cell line. The difference between the two cell clones in their response to asialo-hCG, which was a more potent stimulator of $\mathrm{CHO}-$ TSHr cells than hCG, was even more striking. Interestingly, in our studies, the hCG responsiveness of the two CHO cell clones appeared not to parallel their bTSH sensitivity. This conclusion was further supported by the finding that CAMP production by asialo-hCG approached $30 \%$ that of bTSH in JP09 cells, but less than 6\% that in JP26 cells. Both clones were extremely sensitive to stimulation by $\mathrm{bTSH}$, with a response induced by a concentration as low as $0.001 \mathrm{IU} / \mathrm{L}(0.89$ $\mathrm{pmol} / \mathrm{L}$ ) being readily distinguishable from basal activity. For comparison, in HTC-TSHr cells, the limit of detection was about $0.1 \mathrm{IU} / \mathrm{L}$ bTSH (11). The variation observed in the responses to the various stimulators of the two $\mathrm{CHO}$ cell clones expressing hTSHr was surprising. It may be accounted for by differences in the expression of hTSHr in the two clones. In this respect, the binding studies we conducted indicated a number of hTSHr per cell in the physiological range in JP26 cells, whereas hTSHr density in JP09 cells was more than 10 times higher than that in normal human thyrocytes (31). The possibility that cAMP stimulation was affected in part by a stimulation of endogenous hCG/LH receptors could be excluded, because $\mathrm{CHO}$ wild-type cells were not stimulated by hCG or asialo-hCG.

Another interesting aspect of the study relates to the role of carbohydrate in the thyrotropic activity of hCG in CHOTSHr cells, which was strikingly different from that previously reported in human assay systems. In human thyroid membranes or cells, including HTC cells expressing hTSHr (32), desialylated variants of hCG, although exhibiting markedly increased affinity for hTSHr, were devoid of intrinsic activity and acted as pure antagonists $(11,15,17,33,34)$. In contrast, in CHO-TSHr cells, desialylation of hCG resulted in a marked increase in both its affinity for hTSHr and its cAMP-stimulating activity. This was true for less sialylated isoforms of hCG and enzymatically desialylated hCG. Also, the effect was more pronounced in JP09 cells, which express an exceedingly high receptor density, than in JP26 cells. Cleavage of further carbohydrate, such as galactose, and removal of nearly the total carbohydrate moiety, on the other hand, although slightly improving receptor recognition, exerted a detrimental influence on intrinsic activity in JP09 cells, although asialoagalacto-hCG and deglycosylated hCG were still more active than hCG. Interestingly, JP09 cells closely resemble FRTL-5 cells in this respect, which we have previously shown to be stimulated by desialylated hCG variants (18).

Consistent with these findings, the rodent thyroid has long been recognized to be more sensitive to stimulation by $\mathrm{hCG}$ and desialylated hCG than the human thyroid $(10,26)$. Apparently, the role of carbohydrate in signal transduction varies among cells that differentially express TSHr or different types of cells expressing TSHr. This may explain at least in part the divergent responses to carbohydrate-modified hCG forms observed in various cell lines. As for the $\mathrm{CHO}$ cells expressing hTSHr, although they provide one of the most sensitive tools currently available for measuring thyroid stimulators, their nonthyroid nonhuman descent and the supraphysiological hTSHr number expressed emphasize the fact that any conclusions about the physiological significance of the findings derived from $\mathrm{CHO}$ cells should be drawn with caution. For that reason, at the present time it is not possible to resolve, on the basis of these studies, the ongoing controversy of whether hCG is indeed a thyroid stimulator of significant potency in man. The present findings provide a strong support in favor of the use of human thyroid cell lines, such as HTC, for hTSHr expression studies.

With respect to the existence of molecular forms of hCG with increased thyrotropic activity, the present study revealed a variation in thyrotropic activity among the microheterogeneous isoforms of hCG $(35,36)$. It is important to note that this study, unlike previous studies by Pekary et al. (37) and Yoshimura et al. (38), focused on the isohormones of hCG and did not include variant forms of hCG or fragments thereof, which are known to be present in pregnancy urine or placental tissue extracts. These researchers reported an increased in vitro thyrotropic activity of partially sialated hCG variants extracted from hydatidiform moles of hyperthyroid patients (37). In contrast to their material, our molar hCG was derived from euthyroid patients. The present studies revealed a relation between the pI value of the hCG molecules and their thyrotropic activity in CHO-TSHr JP09 cells, with alkaline isoforms displaying an enhanced potency. This was true for hCG of both pregnancy and molar origin. On the other hand, we found no major differences between the activities of molar hCG and pregnancy hCG or between the isoforms of identical $\mathrm{pI}$ derived from hCGp or hCGm. We conclude that, apart from tumor-derived hCG variants, which may be either highly acidic or basic forms of hCG (37-39), the hCG molecule itself is made up of isohormones that differ in their thyrotropic activity, and even subtle changes in the $\mathrm{pI}$ spectrum of hCG may affect its thyrotropic activity.

In conclusion, both the differential expression of hTSHr and the intrinsic microheterogeneity of the hormone cause a variation in the cAMP response to hCG in CHO-TSHr cells. Both mechanisms may at least in part explain previous observations that the hCG response differs among thyroid cells, particularly when they are derived from different species, and that the correlation between serum hCG concentrations and thyroid hormone levels in patients with trophoblast disease has been generally found to be poor $(10,39-42)$. They may also play a role in modulating the thyroid response to hCG during pregnancy or trophoblast disease.

\section{References}

1. Pierce JG, Parsons TF. 1981 Glycoprotein hormones, structure and function. Annu Rev Biochem. 50:465-495.

2. Vassart G, Dumont JE. 1992 The thyrotropin receptor and the regulation of thyrocyte function and growth. Endocr Rev. 13:596-611.

3. Combarnous Y. 1992 Molecular basis of the specificity of binding of glycoprotein hormones to their receptors. Endocr Rev. 13:670 691.

4. Hershman JM. 1991 Hyperthyroidism caused by trophoblastic tu- 
mors. In: Ingbar SH, Braverman LE, eds. Werner's the thyroid. A fundamental and clinical text, 6 th ed. Philadelphia: Lippincott; 705709.

5. Amir SM. 1986 Human chorionic gonadotropin: a negligible human thyroid stimulator. In: Ingbar SH, Braverman LE, eds. Werner's the thyroid, 5th ed. Philadelphia: Lippincott; 1088-1097.

6. Hershman JM. 1992 Editorial: role of human chorionic gonadotropin as a thyroid stimulator. J Clin Endocrinol Metab. 74:258-259.

7. Mann K, Hoermann R. 1993 Thyroid stimulation by placental factors. J Endocrinol Invest. 16:378-384.

8. Amir SM, Sullivan RC, Ingbar SH. 1980 In vitro responses to crude and purified hCG in human thyroid membranes. J Clin Endocrinol Metab. 51:51-58.

9. Carayon P, Lefort G, Nisula BC. 1980 Interaction of human chorionic gonadotropin and human luteinizing hormone with human thyroid membranes. Endocrinology. 106:1907-1916.

10. Amir SM, Endo K, Osathanondt R, Ingbar SH. 1985 Divergent responses by human and mouse thyroids to human chorionic gonadotropin in vitro. Mol Cell Endocrinol. 39:31-37.

11. Hoermann R, Broecker $M$, Grossmann M, Mann K, Derwahl M. 1994 Interaction of human chorionic gonadotropin (hCG) and asialohCG with recombinant human thyrotropin receptor. I Clin Endocrinol Metab. 78:933-938.

12. Kraiem Z, Sadeh O, Blithe DL, Nisula BC. 1994 Human chorionic gonadotropin stimulates thyroid hormone secretion, iodide uptake, organification, and adenosine $3^{\prime}, 5^{\prime}$-monophosphate formation in cultured human thyrocytes. J Clin Endocrinol Metab. 79:595-599.

13. Parmentier M, Libert F, Maenhaut $C$, et al. 1989 Molecular cloning of the thyrotropin receptor. Science. 246:1620-1622.

14. Perret J, Ludgate M, Libert F, et al. 1990 Stable expression of the human TSH receptor in $\mathrm{CHO}$ cells and characterization of differentially expressing clones. Biochem Biophys Res Commun. 171: 1044-1050.

15. Hoermann R, Amir SM, Ingbar SH. 1988 Evidence that partially desialylated variants of human chorionic gonadotropin (hCG) are the factors in crude hCG that inhibit the response to thyrotropin in human thyroid membranes. Endocrinology. 123:1535-1543.

16. van Hall, Vaitukaitis JL, Ross GT, Hickman JW, Ashwell G. 1971 Immunological and biological activity of hCG following progressive desialylation. Endocrinology. 88:456-464.

17. Hoermann R, Schumm-Draeger PM, Rehbach K, Mann K. 1991 Asialoagalacto-human chorionic gonadotropin, a carbohydratemodified variant of human chorionic gonadotropin, antagonizes the stimulatory actions of bovine thyroid-stimulating hormone on thyroid function and HLA-DR expression in human thyroid in vitro and in vivo. J Clin Invest. 88:1947-1954.

18. Hoermann R, Keutmann HT, Amir SM. 1991 Carbohydrate modifications transform human chorionic gonadotropin into a potent stimulator of adenosine $3^{\prime}, 5^{\prime}$-monophosphate and growth responses in FRTL-5 thyroid cells. Endocrinology. 128:1129-1135.

19. Warren L. 1959 The thiobarbituratic acid assay of sialic acids. J Biol Chem. 234:1971-1975.

20. Spiro RG. 1966 Analysis of sugars found in glycoproteins. Methods Enzymol. 3:7-8.

21. Keutmann HT, McIlroy PJ, Bergert ER, Ryan RJ. 1983 Chemically deglycosylated human chorionic gonadotropin subunits: characterization and biological properties. Biochemistry. 22:3067-3072.

22. Ludgate M, Costagliola S, Danguy D, Perret J, Vassart G. 1990 Recombinant TSH-receptor for determination of TSH-receptor antibodies. Exp Clin Endocrinol. 100:73-74.

23. Goerg A, Postel W, Westermeier R, Gianazza E, Righetti PG. 1980 Gel gradient electrophoresis, isoelectric focusing and two-dimensional techniques in horizontal, ultrathin polyacrylamide layers. J Biochem Biophys Methods. 3:273-284.

24. Kyhse-Andersen J. 1984 A simple horizontal apparatus without buffer tank for electrophoretic transfer of proteins from polyacrylamide gels to nitrocellulose. J Biochem Biophys Methods. 10:203209.

25. Hoermann R, Spoettl G, Grossmann M, Saller B, Mann K. 1993 Molecular heterogeneity of human chorionic gonadotropin in serum and urine from patients with trophoblastic tumours. Clin Investig. 71:953-960.

26. Nisula BC, Ketelslegers JM. 1974 Thyroid-stimulating activity and chorionic gonadotropin in vitro. J Clin Invest. 54:494-499.

27. Davies TF, Platzer M. 1986 hCG-induced TSH receptor activation and growth acceleration in FRTL-5 thyroid cells. Endocrinology. 118:2149-2151.

28. Hershman JM, Lee HY, Sugawara M, et al. 1988 Human chorionic gonadotropin stimulates iodide uptake, adenylate cyclase, and deoxyribonucleic acid synthesis in cultured rat thyroid cells. J Clin Endocrinol Metab. 67:74-79.

29. Tomer Y, Huber GK, Davies TF. 1992 Human chorionic gonadotropin (hCG) interacts directly with recombinant human TSH receptors. J Clin Endocrinol Metab. 74:1477-1479.

30. Yoshimura M, Hershman JM, Pang XP, Berg L, Pekary AE. 1993 Activation of the thyrotropin (TSH) receptor by human chorionic gonadotropin and lutcinizing hormone in Chinese hamster ovary cells expressing functional human TSH receptors. J Clin Endocrinol Metab. 77:1009-1013.

31. Smith BR, McLachlan SM, Furmaniak J. 1988 Autoantibodies to the thyrotropin receptor. Endocr Rev. 9:106-121.

32. Derwahl M, Kuemmel M, Goretzki P, Schatz H, Broecker M. 1993 Expression of the human TSH receptor in a human carcinoma cell line that lacks an endogeneous TSH receptor: growth inhibition by cAMP. Biochem Biophys Res Commun. 191:1131-1138.

33. Carayon P, Amr S, Nisula BC. 1980 A competitive antagonist of thyrotropin: asialo-choriogonadotropin. Biochem Biophys Res Commun. 97:69-74.

34. Amir SM, Sullivan RC, Ingbar SH. 1981 The effect of desialylation on the in vitro interaction of human chorionic gonadotropin with human thyroid plasma membranes. Endocrinology. 109:1203-1211.

35. Greasslin D, Weise HC, Czygan PJ. 1972 Isolation and partial characterization of several different chorionic gonadotropin (hCG) components. FEBS Lett. 20:87-89.

36. Yazaki K, Yazaki C, Wakabayashi K, Igarashi M. 1980 Isoelectric heterogeneity of human chorionic gonadotropin: presence of chorioncarcinoma specific components. Am J Obstet Gynecol. 138:189194.

37. Pekary AE, Jackson IMD, Goodwin TM, Pang XP, Hein MD, Hershman JD. 1993 Increased in vitro thyrotropic activity of partially sialated human chorionic gonadotropin extracted from hydatidiform moles of patients with hyperthyroidism. J Clin Endocrinol Metab. 76:70-74

38. Yoshimura M, Pekary AE, Pang XP, Berg L, Goodwin TM, Hershman JM. 1994 Thyrotropic activity of basic isoelectric forms of human chorionic gonadotropin extracted from hydatidiform mole tissues. J Clin Endocrinol Metab. 78:862-866.

39. Mann K, Schneider N, Hoermann R. 1986 Thyrotropic activity of isoelectric variants of human chorionic gonadotropin from trophoblastic tumours. Endocrinology. 118:1558-1566.

40. Amir SM, Osathanondt R, Berkowitz RS, Goldstein DP. $1984 \mathrm{Hu}-$ man chorionic gonadotropin and thyroid function in patients with hydatidiform mole. Am J Obstet Gynecol. 150:723-728.

41. Norman RJ, Lowings C, Oliver T, Chard T. 1985 Doubts about human chorionic gonadotropin as a thyroid stimulator [Letter]. Lancet. I:1096.

42. Madersbacher S, Schwarz S, Mann K, Klieber R, Wick G, Berger P. 1993 Does tumor-derived human chorionic gonadotropin act as a thyroid stimulator in vivo? Clin Chem. 39:229-233. 